\title{
Preparation and Management of Teaching Practice Process at University of Nairobi, Kenya: Appropriateness of Methods and Resources
}

\author{
Odundo Paul Amollo, Ganira Khavugwi Lilian \\ and Ngaruiya Boniface \\ Department of Educational Communication and Technology, \\ University of Nairobi, \\ Kenya
}

\begin{abstract}
Preparation and management of teaching practice allows for adequate allocation of resources and effective utilization of instructional strategies that permit teacher trainees to adjust to varying situational demands of learning tasks. Teacher trainees with adequate preparation to work facilitate learning process and guide learners in discerning appropriate application of knowledge, skills and attitudes for professional competency. In addition, effective teaching practice begins with authentic preparation through; identifying teaching practice school, attending to briefing prior to posting for teaching practice, gathering teaching practice preparation materials, preparing teaching learning resources and identifying appropriate assessment methods. However, proficiency in preparation and management of teaching practice are among weak areas of professional development in universities in Kenya. If combined with failure in identifying appropriate teaching practice schools, inadequate resources and inefficient class management skills, teaching practice may result in detrimental instructional organization with little concern over learners' needs. This study determined preparation and management of teaching practice process at the University of Nairobi. Anchored on descriptive survey design, the study targeted 68 trainee teachers on teaching practice from 17 Counties sampled randomly. The study used questionnaires and interview schedules to collect data from trainee teachers. For data analysis, the study relied on descriptive and inferential statistics, with data presented using tables and graphs. The results indicated that teacher trainees are adequately prepared for teaching practice. Recommendations advocate for teacher educators to examine relevant preparation strategies and adjustment to ensure that teaching practice is appropriately managed to achieve professional development. Further, Universities and government should create suitable, dependable, diversified and sustainable mechanisms for financing teaching practice exercise.
\end{abstract}

Keywords. Assessment methods; Debriefing; Teaching practice; Teacher trainee; Teaching/Learning resources. 


\section{Introduction}

Teacher education is anchored on cohesive and holistic approaches that support prerequisite for preparing trainees for qualitative and productive professional life. Whereas teacher education is entirely a component of professionalism, effective preparation and management contributes to mastery of teaching, selfregulation and cognitive abilities for nurturing professional competence. Further, effective preparation emphasizes knowledge acquisition, provision of multiple representation and explanations of understanding how content and learning resources in class management are organized and tailored towards diverse interests and abilities of learners. Supporting this assertion, Scott (2016) in a dissertation on character education opined that adequate preparation assists teacher trainees in exhibiting confidence in instructional management, demonstrating improved professional traits and development of self-efficacy which contributes to high learner achievement. Therefore, in cases where teacher trainees are appropriately prepared for teaching practice, there are high chances of managing instructional processes for nurturing professional growth. However report by Ministry of Education (2012) indicated that inadequate funding and investment in educational institutions significantly influence preparation and management of teaching practice in higher learning institutions. In support of this observation, Odundo, Ganira and Kinyua (2018) affirmed that teachers with inadequate preparation demonstrate lower confidence are unresponsive to learner motivation, practice stringent class regulations and depend on extrinsic inducement and negative approvals to get learners to study. Based on this realization, the study examined preparation for teacher trainees at the University of Nairobi through; identifying teaching practice school, attending to briefing prior to posting for teaching practice, gathering teaching practice preparation materials, preparing teaching/learning resources and identifying appropriate assessment methods.

Effective preparation for teaching practice assists teacher trainees to develop confidence, master knowledge of content, and use variety of instructional resources for successful instructional pathways. This is in tandem with Koedel, Parsons, Podgursky, and Ehlert (2012) affirmation in a study on teacher preparation and quality that linkage between preparation programmes and educational research determine adequacy of training for instructional management. With effective teacher preparation programmes, trainees are likely to practice professional class management skills, use appropriate instructional materials and meet demands of class management as effective practitioners. However, Baecher (2012) found teacher preparation programmes inadequate in equipping teacher trainees with sufficient instructional management skills, creating a mismatch between teacher education programmes and actual teaching in class. In supporting this contention, Kagoda, and Sentongo (2015) noted that incompetency among trainees and practicing teachers arise from inadequate preparation and management of teaching practice which in turn weaken professional development and competence. Further still, placement of teacher trainees is a challenge facing universities in Kenya, because of huge numbers placed in schools against expansive geographical regions which is usually the entire country. In a study on teacher education programmes for the $21^{\text {st }}$ century, 
Katitia (2015) attributed unsatisfactory basic preparation of teachers to inadequate resources and insufficient funding as challenges facing teacher education in universities across the country. Further, Hejar, Salma and Hiba (2018) suggested that teacher professional development at university requires conventional societal representation, innovative and didactic approaches, positive attitudes to teaching and consideration for learning styles for all trainees. To achieve this, curriculum developers in teacher preparation programmes should lay emphasis on theoretic component that inadequately address practice and instructional management. This is based on realization that discrepancy between theory and practice in teacher preparation programmes arises from inappropriate preparation as well as insufficient resources for reinforcing professional proficiency.

At the University of Nairobi, teaching practice is used to link course work and instructional management which is crucial in nurturing professional development. However, Kafu (2011) in a study on teacher education in Kenya, found inconsistencies between training courses, programme expectations and nature of teacher trainees' preparedness for teaching practice. Inconsistencies in training courses are likely to hinder effective teacher professional development therefore creating a disconnection between theory and practice. In acknowledging this assertion, Odundo, Kinyua and Ganira (2018) found teacher preparation programmes inadequate in assessing philosophies surrounding the profession and adoption of new strategies in class management skills. This implies that inadequate professional competency stems from exclusively focusing on departmental output to the letter which thwarts the manner in which teaching practice is conducted at University. After failing to address practical challenges facing teacher trainees in universities, Namunga and Otunga (2012) opined that policy-makers often devise reforms which entail more than teacher educators can achieve or which overlook social, ethical or material limitations confronting challenges in teaching practice. Failure to address challenges facing preparation and management of teaching practice could lead to feelings of unpreparedness and disparities among teacher trainees thereby generating experiences of frustration, dissatisfaction and discontentment which weaken professional development.

Drawing from this concern, the government in collaboration with ministry of education, through the Constitution of Kenya (2010) and Sessional papers; no 1 of 2005 and no 14 of 2012 policies acknowledges and supports quality teacher training and development across all learning sectors for professional competence. Further, the Basic Education Act 2013 and article 35(3) of the constitution which aligns education and training to vision 2030, emphasizes a holistic framework for education and professional development for achieving national goals of education. All these support for quality teacher professional development would encourage access, relevance and strengthen productive skills in preparation, resource mobilization and management of teaching practice for effective professional competence and sustainable livelihood. However, though establishment of teacher professional development is 
recommended in policy framework, universities still experience inadequate resources for effective management and support for teaching practice process. With inadequate implementation framework, preparation for practical teaching remains an incoherent program and teacher trainees learn to teach effectively once involved in full-time teaching. In concurrence with this contention, Malechwanzi, Hong and Mbeke (2016) noted that challenges in teacher preparation programmes arise from soaring enrollments in universities, inadequate infrastructure, insufficient policies and management concerns which results in weak professional development. More still, in a study on reflections on teacher education programmes, Akcan (2016) noted that need for more teachers in the country increased teacher education institutions which significantly influence quality of teacher preparation and management. In this regard, effectiveness in preparation for teaching practice requires proper planning in order to correct misconceptions to hopefully produce teachers who can apply knowledge in real contexts for learner achievement and professional growth. Agreeing with these sentiments, Kraut, Chandler, and Hertenstein (2017) affirmed that effectiveness in teaching and learning is attributed to specific characteristics of the teacher including teacher behavior in class, content knowledge, pedagogical orientations, and high levels of preparedness. Further, Heidi and Susan (2018) concluded that nurturing teacher professional growth requires a significant connection between democracy and education that supports citizenship ideals. It was therefore necessary to explore whatever will achieve a breakthrough in appropriate teacher preparation by placing emphasis on authentic methods of; identifying teaching practice school, attending to briefing prior to posting for teaching practice, gathering teaching practice preparation materials, teaching learning resources as well as identifying appropriate assessment methods that will support effective professional competency.

\subsection{Identifying teaching practice school}

Placement in an appropriate school significantly influences teacher trainees' attitudes and beliefs towards instructional practices and professional efficiency. According to Tabot, and Nyandusi (2012), appropriate placement for teaching practice presents an opportunity for both teacher trainees and learner to acquire and retain new knowledge that promotes learning. At the University of Nairobi, teacher trainees choose schools for teaching practice generally considering interests and career goals in relation to skills, values, location and desired working environment. As much as specialization is encouraged, Çakmak (2013) opined that experience prior to establishing a career path is recommended given that the school selected ends up shaping focus of the teacher trainee and goals on commencement. Further, teacher trainees either find a school of choice or rely on academic faculty to provide data bank on teaching practice schools available countrywide as well as conditions and regulations for choosing such institutions. This is supported by a list of potential teaching practice schools and opportunities which are made available each semester to all teacher trainees. Details on selection of school include ; Data bank on teaching practice schools countrywide, distance from tarmac road which is preferably $(10 \mathrm{~km})$, subject combination, school curriculum, workload in the school and in the subject areas, and consideration for special subjects like computer studies and business 
education.. Since teacher trainees at the University of Nairobi do not receive any stipend during teaching practice, most of them prefer picking schools in rural areas which in most cases is inaccessible by university assessors. In such circumstances teacher trainees may end up not receiving maximum assessment of six times, which in turn compromises professional development. Drawing from this concern, Odundo, Kinyua and Ganira (2018) suggested that the University should post trainee teachers to schools with supportive and condusive environment that sustain effective professional growth.

The first experience during teaching practice serves as a foundation for developing the best of each teacher trainee's professional capacity and catalyzes a lifelong investment in goals, skills and values in teaching. This is in tandem with Makori, and Onderi (2013) observation that appropriate teaching practice school accustom teacher trainees' efficiently, reinforce positive performance and encourage professionalism. On the other hand, teaching practice in areas of lowresource settings may not be efficient due to educational priorities from support structures, purchase of instructional materials to implementation of instructional methods. Echoing same contention, Tabot (2015) in a study on characteristics of teaching practice schools and supervision of students, noted that effective professional development starts with placement in a learning institution that meets demands of the teacher. From Tabot (2015) study, financial-related concerns were identified as prevailing factors in posting of teacher trainees to selecting teaching practice schools. Hence, in cases where teacher trainees fail to identify an appropriate school, supervision could be significantly affected owing to challenges beyond control during assessment. Drawing from this observation Ojwang' (2016) suggested that appropriate placement should ensure that the school selected is similar to or almost to that which the teacher trainee will later teach as this could provide confidence, self-esteem plus pleasant surroundings and welcoming cooperating teachers for encouraging professional competence.

\subsection{Briefing prior to posting for teaching practice}

Briefing prior to teaching practice enables trainee teachers to familiarize with occurrences in schools, for effective instructional management, implementation of policies and regulations within selected schools. Echoing these sentiments, Zeichner (2010) opined that acceptable briefing is anchored on constructive association involving contact with realistic understanding and the entire process of experiential learning. Prior briefing sessions are designed to consider concerns of teacher trainees at every step taken on forth coming fieldwork placements. Such sessions include training on: entry to school, orientation, timetabling, scheming, lesson planning, participation in school activities, attendance to briefing sessions, subject content, teacher-learner interaction, teacher-teacher associations and learner-peer rapport. Additionally in an article on the theoryPractice relationship Hatlevik (2011) asserted that valuable information about preparing teacher trainees and supervisors for teaching practice overcomes potential barriers to optimal learning in the placement school. Thus if briefing prior to teaching practice is inappropriate, personal processes ranging from anxiety, confidence or enjoyment tend to have negative impact on instructional management. 
In an article on the work of teacher education, Ellis, Blake, McNicholl, and McNally (2011) pointed out that through briefing, teacher trainees learn responsibilities and expectations, regulations on conduct, guidelines and instructions on assessment procedures. Further, appropriate briefing exercise assists teacher trainees to psychologically navigate through changing experiences from content learnt in college to practical experiences through transition to actual teaching. Through briefing sessions, teacher trainees are inducted on a variety of interpersonal challenges emanating from; learners, regular teachers, school principals, and university assessors who may be likely to influence teaching practice. Given that such challenges may be emotionally upsetting, Parker (2011) affirmed that briefing process should articulate teacher trainee's perception and interpretation of fieldwork. Thus, supervisors should reflect on the learning objectives as well as consider that every teacher trainee completes teaching practice period with a preceding set of individual goals and professional expectations.

\subsection{Provision of teaching practice preparation materials}

Teacher education programmes are anchored on professional training through collaborating with placement schools to ensure quality teaching by providing teacher trainees with preparation materials, MacDonough (2012). At the University of Nairobi, teacher trainees' professional-task accomplishment is accompanied by teaching practice materials and backed by appropriate guidance provisions including; student teaching practice hand book, schemes of work and lesson plan books, school confidential report, supervisor's assessment card, daily diary, teaching practice guide book, time tables, contact person in the school and samples of instructional resources. However, Owuor (2012) noted that insufficient provision of teaching practice materials is due to high enrolment and inadequacy of funding to universities. This challenge has led to stakeholders to raise questions on management of teaching practice, which has been critiqued for compromising professional development. This is in concurrence with Okigal, Nyakundi, Osongo and Nyaboga (2012) assertion that reduced government funding together with increased enrolment and inadequate resources creates challenges to quality education in universities in Kenya. Inadequate provision of teaching practice materials may weaken quality of teaching, curriculum implementation, instructional management and professional growth which in turn cause frustration, dissatisfaction and discontentment among trainee teachers.

Once equipped with adequate teaching practice preparation materials, Sağ (2014) affirmed that teacher trainees reflect and appreciate own sense of professional identity and observe programmes for supplementary assistance within the placement period. Effective teaching therefore occurs where teacher trainees experience appropriate balance with dimensions of class teaching practices including; enhanced activities, demanding tasks and content, and resource mobilization. According to Elliott (2015) these practices are made possible with support of materials that record feedback and appraisal on instruction; enhance self-efficacy, self-regulated learning, confidence and a bold 
step in professional development. Through provision of adequate preparation materials, feedback on assessment is enhanced, effective strategies for review increase, as well as increase in learning outcomes. In this regard, teacher trainees learn what is expected and sets the ground rules for teaching practice experience.

\subsection{Teaching/learning resources for teaching practice}

Pedagogical support by university assessors towards teacher trainees leads to enhanced implementation and innovation of instructional resources during and after placement period. Teaching/learning resources expose learners to simulation which allows retention of new knowledge involving variety of senses. This position is supported by Behm, and Lloyd (2009) suggestion that teacher trainees should incorporate teaching/learning resources appropriately to promote efficiency of learning by improving quality and reinforcing teaching. This is based on realization that teaching/learning resources provide teacher trainees with interesting and persuasive platforms for conveying information as learners get motivated to learn. According to Ashaver and Igyuve (2013) teaching/learning resources include; manipulative, textbooks, magazines, publications online, audio and visual recording, print and non-print resources which need to match specific contexts. For effective teaching to be realized, teacher trainees should use teaching/learning resources that grasp learners' attention.

However, Akyeampong, Luisser, Pryor and Westbrook (2013) noted that teacher training programmes frequently emphasize on intellectual sensitivity including course content and fail to acknowledge pedagogical approaches which weaken instructional grounding for trainee teachers. Appropriate adoption of teaching resources improves learners' knowledge abilities and skills, which are used to monitor assimilation and contribute to intellectual development. For this reason, the government of Kenya acknowledges institutional structures geared towards quality education and training in teacher educational programmes as indicated in the Kenya Education Sector Support Plan 2005-2010 and the National Educational Sector Plan 2014-2018). This is upon realization that teaching/learning resources reinforce authentic, relevant and effective driving concepts for sustained learning.

\subsection{Appropriateness of assessment methods during teaching practice}

Assessment is the process of obtaining information used for making decisions about learners, curriculum and educational policy for realization of quality teaching and learning process. As noted by Ferguson (2010) appropriate assessment methods provide frequent and immediate feedback to learners with emphasis on; learning objectives, creation of optimum class climate, and reflection on teaching to improve learning achievement. This would expose teacher trainee's perception to the role of practicum towards professional growth in terms of placement school environment, personalized relationships between teacher trainee and learners as well as ecological variables. In agreeing with these sentiments Oluwatayo, and Adebule (2012) indicated that relevant assessment demonstrates proficiency in skills and indentifies areas of weakness in knowledge of content area or curriculum itself. Such evidence is observed 
through: lesson plan, sequence of content, lesson introduction and development, use of teaching and learning resources, class management, evaluation and achievement of objectives, as well as confidence levels of the teacher trainee.

However, Wambugu, Barmao, and Ng'eno, (2013) noted that during teaching practice, assessment which is usually a minimum of six valuations is hampered by shortage of supervisors. As a consequence, teacher trainees end up with either one or two assessments, which is likely to compromise professional growth. Further still, debriefing and feedback sessions of observed trainees seems inadequate since a supervisor might end up posted to assess several trainee teachers in different schools that are not of close proximity. In this regard, a supervisor is forced to leave amid the sessions to supervise other teacher trainees without providing appropriate support, mentorship, guidance and debriefs to the observed trainee. Commenting on this position, Odundo, Othuon and Ganira (2017) indicated that effectiveness of teaching practice is dependent upon roles played by assessors in implementing supervisory approaches by virtue of expertise and experience in helping professional development among teacher trainees. To achieve this, teacher preparation programmes should focus on competence in collecting, analyzing and utilizing of assessment information for nurturing professional competence. It is based on this background that the study sought to examine preparation and management of teaching practice process at the University of Nairobi.

\section{Statement of the problem}

Preparation of trainee teachers in Kenya has a strong gap between theory and practice owing to emphasis laid on theoretical work. If combined with failure to identify appropriate teaching practice schools, inadequate resources and inefficient class management skills, teaching practice results in detrimental instructional organization with little concern over learner's needs and professional growth. In this regard, preparation for practical teaching appears like a disjointed program due to inadequate preparation and management of teaching practice process. As a result of inadequate preparation, teacher trainees learn to teach effectively once engaged in full-time teaching. Though establishment of teacher professional development is proposed in Sessional Paper of 2005 and 2012, there are no clear implementation guidelines which in turn lead to incompetency. Based on these observations, addressing inadequacies in teacher preparation requires authentic knowledge and skills that begins with adequate preparation in: identifying teaching practice school, attending to briefing prior to posting for teaching practice, gathering teaching practice preparation materials, teaching learning resources and determining appropriate assessment methods. In cases where teacher trainees are adequately prepared for teaching practice, there are high chances of correcting misconceptions to hopefully produce teachers who will apply knowledge in real contexts for learner achievement. On the other hand, where feelings of unpreparedness and disparities exist in teacher preparation programmes, teacher trainees may experience frustration, dissatisfaction and discontentment weakening professional development. It was therefore vital to examine 
preparation and management of teaching practice process at the University of Nairobi.

\section{Purpose and objectives}

The purpose of the study is to examine preparation and management of teaching practice process at the University of Nairobi. The objective was to establish:

a) Effectiveness of methods used in identifying teaching practice school.

b) Usefulness of attending to briefing prior to posting for teaching practice.

c) Extent to which provision of teaching practice preparation materials influence professional competence.

d) Availability of teaching and learning resources used for teaching practice.

e) Appropriateness of assessment methods used during teaching practice

\section{Theoretical Perspective}

Burdens' (1980) perspective of teacher development anchored the study which was derived from Fuller's (1969) perception of teacher development. Identical to all human beings, teachers develop throughout careers and mature professionally from novice teacher to an experienced one. During early years of professional growth, the teacher is hardly in the same category in later years. This is due to the fact that teachers experience rapid growth and development throughout careers owing to experiences in class, personal learning opportunities and occurrences in life. According to Burden (1979), teachers go through several stages of professional development consisting of numerous phases. The first year of training consists of the survival or adjustment stage, followed by mature stage in the second year of teaching. The mature stage consists of the fifth year of teaching. In the earliest stages of professional development, the educator may experience inadequate information of pedagogical approaches, planning for teaching, keeping learner records, encouraging and mentoring learners. Teachers may also become anxious of applying new techniques of teaching and experience challenges in instructional management. Thus, preparing teacher trainees for effective teaching practice requires explicit knowledge and skills essential not only for expertise but also developing high extent confidence of breaking down ability to allow learning to take place.

All through the second stage, teachers gain confidence in planning and organizing content, and improve in teaching methods due to experiences encountered earlier. After attaining confident in basic instructional methods, teachers learn new strategies and are able to relate content to learner needs. The teacher feels appropriately organized and is able to organize future plans and anticipate events in for achieving learner requirements. Finally during the final stage in professional development, the teacher applies effective planning and organizational skills. Having gotten additional experience, the teacher is able to respond to situations arising from school where discipline becomes an 
established part of class management and not a challenge. Based on theory of teacher development, quality teaching practice begins with adequate preparation through; identifying teaching practice school, attending to briefing prior to posting for teaching practice, gathering teaching practice preparation materials, teaching learning resources and appropriate assessment methods. In instances where teachers prepare effectively for teaching practice, there are high chances of improved learning, increased participation, enhanced confidence and self-efficacy which is critical for learner achievement.

\section{Conceptual Framework}

The conceptual frame work is anchored on five themes essential for preparing teacher trainees for teaching practice through; identifying teaching practice school, attending to briefing prior to posting for teaching practice, gathering teaching practice preparation materials, teaching learning resources and determiningappropriate assessment methods. The framework centers on the premise that if teacher trainees prepare effectively for teaching practice, there are high chances of improved learning, increased participation, enhanced confidence and self-efficacy critical for learner achievement. Furthermore for enhanced learning achievement, the learning environment requires effective support structures including; collaborative teachers, appropriate instructional strategies, feedback, content and curriculum knowledge. The five themes of the conceptual framework determine effectiveness of teaching practice.

a) Identifying teaching practice school: The process of identifying teaching practice school depends on; Data bank on teaching practice schools countrywide, distance from tarmac road $(10 \mathrm{~km})$, subject combination, school curriculum, workload in the school and in the subject areas, special subjects like P.E., IT and business studies.

b) Attending to briefing prior to posting for teaching practice: Briefing allows teacher trainees to: (i) consider familiarity of content (ii) express insights on anticipated practices (iii) expand suitable approaches of presenting personal concerns (iv) build up ability for sustaining and acknowledging diverse perspectives (v) consider suitable methods for class management and (vi) integrate theory into a personal actual teaching.

c) Gathering teaching practice preparation materials:Professional-task accomplishment is accompanied by teaching practice materials and backed by appropriate guidance materials including; student teaching practice hand book, schemes of work, lesson plan books, school confidential report, supervisor's assessment card, daily diary, teaching practice guide book, time table, contact person in the school, samples of instructional resources.

d) Teaching learning resources: teaching/learning resources include; manipulative, textbooks, magazines, publications online, audio and visual recording, print and non-print resources which must match specific contexts and allow effective learning to take place.

e) Determining appropriate assessment methods: Effective teacher preparation result in competence in collection, analysis and utilization of assessment information for improving learner achievement. 


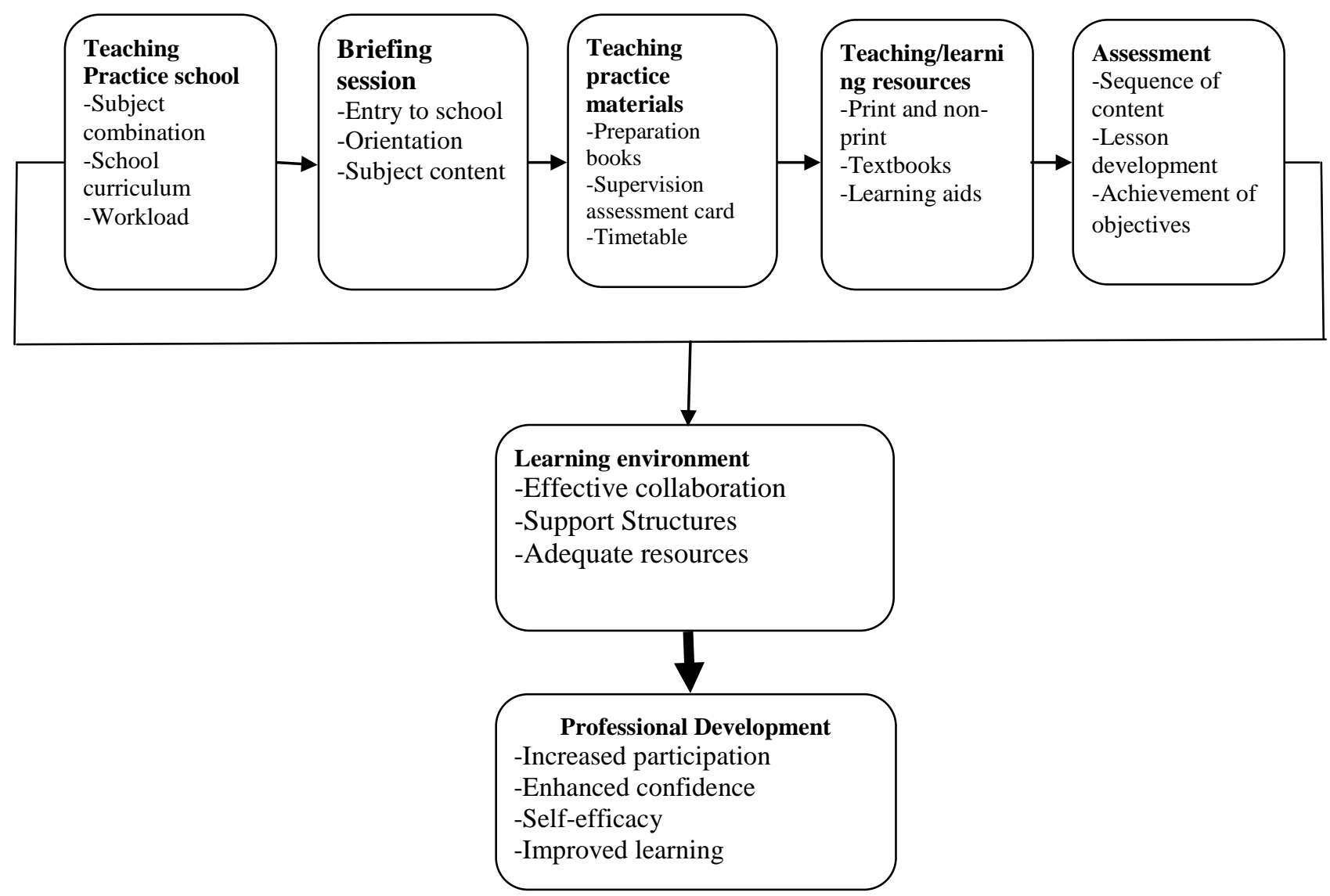

Figure 1: Conceptual Framework on Preparation and Management of Teaching Practice and Appropriateness of Methods and Resources.

\section{Methodology}

The study was anchored on descriptive survey research design to explore themes emerging from preparation and management of teaching practice and appropriateness of methods and resources available at University. According to Kombo and Tromp (2006) descriptive survey design describe occurrences in their natural phenomenon. Description is conducted to influence improvement of a situation. The study randomly sampled 68 teacher trainees from University of Nairobi who were conducting teaching practice within 17 Counties in Kenya. Data collection process took place for a period of three months in 17 Counties randomly selected by external moderators. Out of the 68 trainee teachers randomly sampled, 44 were males while 24 were females. To capture level of preparedness for teaching practice, the study used questionnaires which were open-ended and interview schedules collect data. Specifically, the questionnaire collected data on: identifying teaching practice school and usefulness of attending to briefing prior to posting for teaching practice. The probing technique was used to obtain responses.Interview schedules provided an effective understanding on level of preparedness regarding; gathering teaching practice preparation materials, teaching learning resources and determining appropriate assessment methods. For data analysis the study used descriptive and inferential statistics where graphs, frequencies and percentages were 
utilized in comparisons across categories. Ethical consent and confidentiality were upheld during data collection.

\section{Findings}

\section{1: Characteristics of the Respondents and Schools}

There were a total of 68 respondents out of whom 44 (64.7\%) were male and 24 $(35.3 \%)$ were female drawn from 68 schools where the teacher trainees were undertaking practice and distributed in 17 Counties. The response rate was $100 \%$ with distribution of respondents based on concentration of trainee teachers during teaching practice and the expanse of the region. Nairobi County had the highest number of respondents followed by Mombasa and Homabay. Murang'a and Uasin had the lowest number of respondents given the fewer students who chose to practice teaching in the respective Counties.

\section{2: Overall preparedness}

Appropriate preparation for teaching practice is considered as a critical metacognitive element that helps in planning through reflection, awareness, control and intellectual action. In this regard, the study explored overall preparedness for teaching practice. Findings are shown in Table1.

Table 1: Preparation for teaching practice

\begin{tabular}{|rl|r|r|r|r|}
\hline & Frequency & Percent & Valid Percent & \multicolumn{1}{c|}{$\begin{array}{c}\text { Cumulative } \\
\text { Percent }\end{array}$} \\
\hline \multirow{3}{*}{ Valid $\quad$ Very well } & 16 & 23.5 & 23.5 & 23.5 \\
& Total & 52 & 76.5 & 76.5 & 100.0 \\
& 68 & 100.0 & 100.0 & \\
\hline
\end{tabular}

According to findings in Table 1, out of 68 respondents16 (23.5\%) indicated that they were well prepared for teaching practice. These teacher trainees acknowledged that curricular content at University was adequate which in turn provided relevant practical activities that supported field work. This finding suggests that when the teacher trainee is prepared, lessons run smoothly which leads to effective class management. Further still, majority, 52 (76.5\%) showed that preparation for teaching practice was very adequate. The teacher trainees owned this to the fact that University of Nairobi recognizes teaching practice as a foundation for developing the best of each teacher trainee's professional capacity which catalyzes a lifelong investment in goals, skills and values for nurturing professional growth. These finding corroborates with an earlier finding of Williams, and Williams (2010) who observed that teacher trainees with adequate preparation exhibit confidence in instructional management, demonstrate improved professional traits, have self-efficacy which contributes to high learner achievement. 


\section{3: Identifying teaching practice school.}

Teacher trainees choose schools for teaching practice generally considering interests and career goals in relation to skills, values, location and desired working environment. The study sought to examine methods used in identifying teaching practice schools. Findings are shown in Table 2.

Table 2: Methods used for identifying Teaching Practice School

\begin{tabular}{|c|c|c|c|c|c|}
\hline & Frequency & Percent & Valid Percent & $\begin{array}{l}\text { Cumulative } \\
\text { Percent }\end{array}$ \\
\hline \multirow{6}{*}{ Valid } & Very dissatisfied & 3 & 4.4 & 4.4 & 4.4 \\
\hline & Dissatisfied & 2 & 2.9 & 2.9 & 7.4 \\
\hline & Neutral & 6 & 8.8 & 8.8 & 16.2 \\
\hline & Satisfied & 13 & 19.1 & 19.1 & 35.3 \\
\hline & Very satisfied & 44 & 64.7 & 64.7 & 100.0 \\
\hline & Total & 68 & 100.0 & 100.0 & \\
\hline
\end{tabular}

At the University of Nairobi, teacher trainees pick teaching practice school of choice considering procedures and conditions of the institution. When asked about methods used in picking placement school, findings from Table 2 show that out of 68 respondents, $3(4.4 \%)$ were very dissatisfied on preparation acquired while $2(2.9 \%)$ were dissatisfied. These trainee teachers lamented that some of the schools were located in remote areas which made access difficult for them and the University assessors. Further, these trainee teachers indicated that when selection of placement school is inadequate, supervision is affected such that they are sometimes penalized for issues beyond control during assessment since the institutional background is rarely considered as crucial. Based on these responses, for successful teaching to be realized, teacher trainees require support in selecting schools that match curriculum to expectations of the environment such that authenticity of teaching is not overwhelmed to the point where discrepancy exists. Further, 6(8.8\%) remained neutral and 13 (19.1\%) showed satisfaction in methods used in identifying schools for teaching practice. On the other hand, majority of the trainee teachers, 44 (64.7\%) were very satisfied with methods of identifying teaching practice school. These finding agree with the work of Tabot, (2015) who opined that background characters of schools used for practice influence teacher trainees' achievements.

\section{4: Briefing prior to teaching posting}

Briefing prior to posting assists teacher trainees to psychologically and virtually progress from course work experience and transit to real class setting. This study determined quality of briefing prior to teaching posting. Study findings are shown in Table 3. 
Table 3: Quality of briefing prior to posting for teaching Practice

\begin{tabular}{|c|c|c|c|c|c|}
\hline & Frequency & Percent & Valid Percent & $\begin{array}{c}\text { Cumulative } \\
\text { Percent }\end{array}$ \\
\hline \multirow{6}{*}{ Valid } & Very dissatisfied & 2 & 2.9 & 2.9 & 2.9 \\
\hline & Dissatisfied & 2 & 2.9 & 2.9 & 5.9 \\
\hline & Neutral & 7 & 10.3 & 10.3 & 16.2 \\
\hline & Satisfied & 18 & 26.5 & 26.5 & 42.6 \\
\hline & Very satisfied & 39 & 57.4 & 57.4 & 100.0 \\
\hline & Total & 68 & 100.0 & 100.0 & \\
\hline
\end{tabular}

Briefing engages insights and concerns of teacher trainees on forthcoming fieldwork experience for preparation to overcome likely barriers in dealing with instructional management during the placement period. Cumulatively, out of 68 respondents, $39(57.4 \%)$, felt that briefing received before placement reflected on practice positively and $18(26.5 \%)$ found the sessions satisfactory. This was attributed to the support received from University assessors who provided guidance and mentorship during briefings. However, $2(2.9 \%)$ of the trainee teachers were not contented with the briefing received. Another $2(2.9 \%)$ were utterly dissatisfied with the briefing while $7(10.3 \%)$ remained neutral. The trainee teachers indicated that briefings were inadequate since University assessors did not prepare them sufficiently on challenges they experienced during teaching practice. These findings corroborates with Zeichner, (2010) who asserted that proper consultation is anchored on positive association between understanding of processes of learning and practice in real class settings.

\section{5: Provision of teaching practice preparation materials.}

Provision of adequate preparation materials creates opportunities for novice teachers to navigate through class management processes. Study findings are indicated in Table 4

Table 4: Provision of Teaching Practice preparation materials

\begin{tabular}{|c|c|c|c|c|c|}
\hline & & Frequency & Percent & Valid Percent & $\begin{array}{c}\text { Cumulative } \\
\text { Percent }\end{array}$ \\
\hline \multirow{7}{*}{ Valid } & Very dissatisfied & 2 & 2.9 & 3.0 & 3.0 \\
\hline & Neutral & 4 & 5.9 & 6.0 & 9.0 \\
\hline & Satisfied & 15 & 22.1 & 22.4 & 31.3 \\
\hline & Very satisfied & 46 & 67.6 & 68.7 & 100.0 \\
\hline & \multirow[t]{2}{*}{ Total } & 67 & 98.5 & 100.0 & \\
\hline & & 1 & 1.5 & & \\
\hline & Total & 68 & 100.0 & & \\
\hline
\end{tabular}


Analysis from Table 4, show that teaching practice materials were provided efficiently since $46(67.6 \%)$, of the 68 trainee teachers were very satisfied, while $15(22.1 \%)$ expressed satisfaction with the same. This was an indication that when equipped with teaching practice materials, trainee teachers were ready for instructional process with confidence. In a departure from this, further analysis showed that $2(2.9 \%)$ of trainee teachers were very dissatisfied with the provision of materials while left $4(5.9 \%)$ remained neutral. The trainee teachers lamented that materials were provided when they were almost completing teaching practice which caused them to use own resources in developing lesson plan books. These suggests that delay in providing teaching practice materials could have caused anxiety and distress which in turn influenced learning outcomes. This finding contradicts the work ofSağ (2014) who indicated that once equipped with adequate teaching practice preparation materials, teacher trainees reflect and appreciate own sense of professional teacher identity and observe programmes for supplementary assistance within the placement period.

\section{6: Availability of teaching/learning resources}

Appropriate teaching/learning process enables learners to be exposed to some form of simulation which allows retention of new knowledge involving more than one sense. The study sought to determine the availability of teaching/learning resources during teacher preparation at the university. The study findings are illustrated in Table 5 and 6.

Table 5: Availability of teaching/learning resources at university

\begin{tabular}{|c|c|c|c|}
\hline & & Frequency & Percent \\
\hline \multirow{7}{*}{ Valid } & Dissatisfied & 4 & 5.9 \\
\hline & Neutral & 11 & 16.2 \\
\hline & Satisfied & 18 & 26.5 \\
\hline & Very satisfied & 31 & 45.6 \\
\hline & \multirow[t]{2}{*}{ Total } & 64 & 94.1 \\
\hline & & 4 & 5.9 \\
\hline & Total & 68 & 100.0 \\
\hline
\end{tabular}

Study findings from Table 5, show that out of 68 trainee teachers, 31 (45.6\%) were very satisfied with availability of teaching and learning resources, and 18 $(26.5 \%)$ were satisfied. The trainee teachers indicated that availability of teaching/learning resources fulfilled their pedagogical requirements. In line with these findings, Popham, and Ryan (2012) asserted that the measure to which learning objectives are achieved depends to a large extent on the instructional materials and methodology applied. Additional findings show that $4(5.9 \%)$ of the trainee teachers were dissatisfied with adequacy of teaching/learning materials while $11(16.2 \%)$ were neutral. These trainee teachers 
felt that inadequate instructional resource contributed to anxiety and stressful moments which influenced their achievement during teaching practice. This is in concurrence with Akyeampong, Luisser, Pryor and Westbrook (2013) affirmation that inadequate teaching/learning resources creates feelings of frustration, dissatisfaction, anxiety that leads to low efficacy among teachers.

Table 6: Availability of teaching/learning resources at university

\begin{tabular}{|c|c|c|c|}
\hline & & Frequency & Percent \\
\hline \multirow{8}{*}{ Valid } & Very dissatisfied & 1 & 1.5 \\
\hline & Dissatisfied & 3 & 4.4 \\
\hline & Neutral & 10 & 14.7 \\
\hline & Satisfied & 18 & 26.5 \\
\hline & Very satisfied & 33 & 48.5 \\
\hline & Total & 65 & 95.6 \\
\hline & System & 3 & 4.4 \\
\hline & Total & 68 & 100.0 \\
\hline
\end{tabular}

Analysis from Table 6 show availability of teaching/learning resources used for teaching practice at university. Out of 68 teacher trainees sampled, 33(48.5\%) were very satisfied with availability of teaching/learning resources and $18(26.5 \%)$ were satisfied. The trainee teachers acknowledged that availability of teaching/learning resources assisted them in preparing for teaching practice. These analyses however, disagree with Akyeampong, Luisser, Pryor and Westbrook (2013) assertion that teacher training programmes frequently concentrate on intellectual awareness including scholarly achievement, instructional strategies without considering groundwork preparation for teaching. Further still, 1(1.5\%) of trainee teachers very dissatisfied, 3(4.4\%), felt dissatisfied and 10(14.7\%), remained neutral on the availability of these teaching resources. These were specifically trainee teachers undertaking external studies who failed to conduct the University regularly to access available resources.

\section{7: Assessment methods for teaching at the university}

Effective assessment methods provide frequent and immediate feedback on instructional management. To affirm this, teacher trainees were asked on appropriateness of assessment methods during teaching practice. Study findings are shown in Table 7 and 8. 
Table 7: Appropriateness of assessment methods for teaching at university

\begin{tabular}{|c|c|c|c|}
\hline & & Frequency & Percent \\
\hline \multirow{5}{*}{ Valid } & Very dissatisfied & 1 & 1.5 \\
\hline & Neutral & 4 & 5.9 \\
\hline & Satisfied & 19 & 27.9 \\
\hline & Very satisfied & 44 & 64.7 \\
\hline & Total & 68 & 100.0 \\
\hline
\end{tabular}

Findings in Table 7 attribute positively to appropriateness of the assessment methods used at the university as $44(64.7 \%)$ who represented a large portion of the sampled population, were very satisfied with the assessment methods used for teaching at the university and $19(27.9 \%)$ were satisfied. These were attributed to the fact that all facets of learning were assessed including; lesson plans, introduction, lesson development, resources used, class management skill and personal factors which contributed to their professional development. On the other hand, $4(5.9 \%)$ of the trainee teacher were neutral while $1(1.5 \%)$ were not satisfied with the assessment methods at the university. In agreement with the findings, Odundo, Othuon and Ganira (2017) opined, that effectiveness of teaching practice is dependent upon role played by assessors in implementing supervisory approaches by virtue of expertise and experience in helping professional development among teacher trainees. Furthermore, teaching practice should result in competence in achievement of learning objectives, content delivery, pedagogical approaches and appropriate utilization of instructional resources for professional growth.

Table 8: Appropriateness of assessment methods at university

\begin{tabular}{|c|c|c|c|}
\hline & & Frequency & Percent \\
\hline \multirow{8}{*}{ Valid } & Very dissatisfied & 1 & 1.5 \\
\hline & Dissatisfied & 1 & 1.5 \\
\hline & Neutral & 3 & 4.4 \\
\hline & Satisfied & 17 & 25.0 \\
\hline & Very satisfied & 40 & 58.8 \\
\hline & Total & 62 & 91.2 \\
\hline & System & 6 & 8.8 \\
\hline & Total & 68 & 100.0 \\
\hline
\end{tabular}

Findings in Table 8 show that out of 68 trainee teacher used in the study, $40(58.8 \%)$ were very satisfied and $17(25.0 \%)$ were satisfied with the 
appropriateness of assessment methods used at University. These findings suggest that assessment methods at university could have significantly influenced teaching practice process. In corroboration with these findings Oluwatayo, and Adebule (2012) indicated that relevant assessment approaches demonstrates proficiency in skills and indentifies areas of weakness in knowledge of content area or curriculum itself. Such evidence is observed through: lesson plan, sequence of content, lesson introduction and development, use of teaching and learning resources, class management, evaluation and achievement of objectives, as well as confidence levels of the teacher trainee. Further, $1(1.5 \%)$ were dissatisfied and $1(1.5 \%)$ were very dissatisfied while $3(4.4 \%)$ were undecided. This is evident that notwithstanding challenges, supervisors and assessors at the University of Nairobi employ effective assessments which nurture professional development.

\section{Conclusion}

Teaching practice is the core and insightful segment of the teaching profession. The study makes conclusion based on study findings. The study revealed that teacher trainees at the University of Nairobi were adequately prepared for teaching practice. In regard to overall preparedness, teacher trainees, 52(76.5\%) were satisfied with preparedness for teaching practice. However, the study found mixed reactions in regard to preparedness in various segments critical in teaching practice. A large proportion, $44(76.70 \%)$ were satisfied with methods used for identifying teaching practice school; 39(57.40\%) were satisfied with quality of briefing prior to teaching posting, $46(67.60 \%)$ were satisfied with provision of teaching practice preparation materials. However out of 68 respondents, $4(5.9 \%)$ were dissatisfied with the availability and adequacy of instructional resources provided at the university. This position was generally aggravated by inadequate resources and poor management of teaching practice. On the other hand, 33(48.5\%) were satisfied with the availability of teaching/learning resources while 62 (91.20\%) were satisfied with appropriateness of assessment methods at university. It is therefore concluded that though teacher trainees are adequately prepared at the University of Nairobi, there is need for quality preparation and management of teaching practice by laying emphasis on provision of adequate resources and appropriate assessment for nurturing professional competence.

\section{Recommendations}

Drawing from the findings, the study made recommendations for policy, practice and for further research

\section{Recommendation For policy}

- University requires coherent and supportive policies that will restructure placement of teacher trainees, provision of teaching practice materials, availability of teaching/learning materials, and assessment strategies.

- The Ministry of education should enact effective policies emphasizing adequate professional preparation ascribed to teacher trainees' conceptions and professional course work. 


\section{Recommendation For practice \\ Placement}

- Trainee teachers need to be posted to schools that within close proximity to each other to allow essay access by supervisors.

- The University of Nairobi should give stipend during teaching practice to avoid teacher training from picking schools in rural areas which in most cases are inaccessible by university assessors.

\section{Teaching/learning resources}

- Supervisors to assist trainee teachers in improvising appropriate teaching and learning resources and assist in adjusting lessons plans for better learning achievement.

- There is need for an enhanced consideration of effective use, implementation and innovation of instructional resources during and after placement period.

- The university needs to ensure that teaching/learning resources are available and adequate before commencement of teaching practice.

\section{Provision of teaching practice materials}

- The university needs to ensure that teaching practice materials are distributed to teacher trainees before commencement of teaching and not given out by assessors during approval of schemes of work and lesson plans.

\section{Methods of assessment}

- Supervisors need to inform teacher trainees earlier about visitation and not make spontaneous visits as this often causes tension.

- Teacher trainees need appropriate feedback from assessors and not just awarding grades given that teaching practice is not significant to teacher trainees without criticism is reflective and informative.

- For appropriate assessment to be realized, university should ensure that supervisors are conversant with the content subject.

\section{Recommendation For further studies}

\section{The study recommends that further studies should be carried out on;}

a) Effectiveness of methods used in identifying teaching practice school.

b) Usefulness of attending to briefing prior to posting for teaching practice.

c) Extent to which provision of teaching practice preparation materials influence professional competence.

d) Availability of teaching and learning resources used for teaching practice.

e) Appropriateness of assessment methods used during teaching practice

\section{References}

Akcan, S. (2016). Novice non-native English teachers' reflections on their teacher education programmes and their first years of teaching. Profile Issues in Teachers' Professional Development, 18(1), 55-70. 
Akyeampong, K., Lussier, K., Pryor, J., \& Westbrook, J., (2013).Improving teaching and learning of basic maths and reading in Africa: does teacher preparation count? International Journal of Educational Development, 33, pp. 272-282.

Ashaver, D., \& Igyuve, S. M., (2013). The Use of Audio-Visual Materials in the Teaching and Learning Processes in Colleges of Education in Benue State-Nigeria.IOSR Journal of Research \& Method in Education.e-ISSN: 2320-7388,p-ISSN: 2320-737X Volume 1, Issue 6: PP 44-55.

Baecher, L. (2012). Feedback from the field: What novice preK-12 ESL teachers want to tell TESOL teacher educators? TESOL Quarterly, 46(3), 578-588.

Behm, S. L., \& Lloyd, G. M. (2009). Factors influencing student teachers' use of mathematics curriculum materials. In J. T. Remillard, B. A. Herbel-Eisenmann, \& G. M. Lloyd (Eds.), Mathematics teachers at work: Connecting curriculum materials and classroom instruction New York: Routledge. (pp. 206-222).

Burden, Paul R., (1979).Teachers' Perceptions of the Characteristics and Influences on their Personal and Professional Development. Columbus, Ohio. Ohio State University.

Çakmak, M., (2013). Learning from Teaching Experiences: Novice Teachers' Thoughts. H. U. Journal of Education, 1 (1): 55-67.

Darling-Hammond, L. \& Rothman, R. (Eds.) (2011).Teacher and Leader Effectiveness in High Performing Education Systems. Washington, DC: Alliance for Excellent Education \& Stanford, CA: Stanford Center for Opportunity Policy in Education (CREDO).

David Melita Ole Katitia, (2015). Teacher Education Preparation program for the 21st Century. Which way forward for Kenya? Journal of Education and Practice www.iiste.org ISSN 2222-1735 (Paper) ISSN 2222-288X Vol.6, No.24, pp 57-63.

Elliott, K. (2015). Teacher Performance Appraisal: More about Performance or Development? Australian Journal of Teacher Education, 40(9).http://dx.doi.org/10.14221/ajte.2015v40n9.6.

Ellis, V. (2010) 'Impoverishing experience: The problem of teacher education in England', Journal of Education for Teaching 36, 1: pp 105 -120.

Ferguson, R. F., (2010). Student perception of teaching effectiveness. National Centre for Teacher Effectiveness on the Achievement Gap and Value; Harvard University.

Fuller, F. F. (1969). Concerns of Teachers: A Developmental Conceptualization. American Educational Research Journal, 6, 207-226.

Hatlevik, J. K., (2011). The Theory-Practice relationship: reflective skills and theoretical knowledge as key factors in bridging the gap between theory and practice in initial nursing education. Journal of Advanced Nursing, 68 (4), 868-877.

Heidi, B., Susan, C.L. (2018). Norwegian Teacher Educators' Attentiveness to Democracy and their Practices. International Journal of Learning, Teaching and Educational Research. Vol.17, pp. 26-42,https://doi.org/10.26803/ijlter.17.7.2

Hejar, B.J., Salma, M., and Hiba, A.K. (2018). International Journal of Learning, Teaching and Educational Research. Vol.17, No. 7, pp. 120-34, https://doi.org/10.26803/ijlter.17.7.8

Kafu Patrick A., (2011). Teacher Education in Kenya: Emerging Issues. International Journal of Curriculum and Instruction Vol. 1(1), pp. 43 - 52.

Kagoda, A. M., \& Sentongo, J., (2015).Practicing Teachers' Perceptions of Teacher Trainees: Implications for Teacher Education. Universal Journal of Educational Research 3(2): 148-153.

Katitia,D.M, (2015). Teacher Education Preparation programme for the $21^{\text {st }}$ Century. Which way forward for Kenya?Journal of Education and Practice. ISSN 2222-1735. Vol.6 No. 24, pp.56-63.

Koedel, C., Parsons, E., Podgursky, M., \&Ehlert, M. (2012). Teacher preparation programs and teacher quality: Are there real differences across programs? 
Washington, DC: National Center for Analysis of Longitudinal Data in Education Research.

Makori, A., \& Onderi, H. (2013).Challenges in achieving effective recruitment of secondary school teachers in Kenya. International Journal of Advanced Research in Management and Social Sciences, 2(3), 39-63.

Malechwanzi, J.M., Hong, S. and Mbeke, C. (2016). Policies of access and quality of higher education in China and Kenya: A comparative Study. International \& Comparative Educational Research: 3: 1201990.

McDonoug, G.P., (2012). Teaching PR actioners about Theory and Practice: A proposal to recover Aristotle in education. Journal of Thought, Winter, 7-22.

Ministry of Education Science and Technology, (2012). A policy Framework for Education and Training. Reforming Education in Kenya. Government Press.

Namunga, N.W., \&Otunga, R.N., (2012).Teacher Education as a Driver for Sustainable Development in Kenya. International Journal of Humanities and Social Science Vol. 2 No. 5; 228-234.

Ochanji, M., Ayot, H. O., Kamina, P., Ondigi, S., \& Kimemia, J. N., (2015).Improving Student Teaching for Quality Teacher Preparation: A Kenyan University Case.African Journal of Teacher Education, Vol 4, No

Odundo, P. A., Ganira, K .L. \& Kinyua, G.W. (2018). Experiential Learning, Conditional Knowledge and Professional Development at University of Nairobi, Kenya. Focusing on Preparedness for Teaching Practice. International Education Studies; Vol.11, No. 7; pp 125-135.

Odundo, P. A., Othuon, L., \& Ganira, K. L., (2017). Assessors, School Support and Teaching Practice at the University of Nairobi Kenya: Addressing Teacher Professional Competence. World Journal of Educational Research, Vol. 4(3). pp 430-447.

Odundo, P.A., Kinyua, G. W., \& Ganira, K. L., (2018). Work-based Learning, Procedural knowledge, and teacher trainee preparedness towards teaching practice at the University of Nairobi, Kenya. International Journal of Learning and Educational Research. Vol. 17, 3, pp 96-110.

Ojwan'g, M. A., (2016). Effects of the Restructuring of Teacher Placement on Teacher and Gender Distribution In Public Secondary Schools In Nakuru County, Kenya. Baraton Interdisciplinary Research Journal (2016), 6pp. 83-92.

Okiogal, K.C., Nyakundi, E., Onsongo, Y. \& Nyaboga, B. (2012). Quality Issues in the Expansion of University Expansion in Kenya: The Human Resource Challenges and Opportunities. Chinese Business Review, 596-605.

Oluwatayo, J. A., \& Adebule, S. O., (2012). Assessment of Teaching Performance of Student-teachers on Teaching Practice. International Education Studies; Canadian Center of Science and Education 109, Vol. 5, No. 5; 1913-9039.

Owino Erick Ajuok, (2014). Quality of Teacher Training In Concurrent Program in Primary Teacher Colleges, Homa-Bay County, Kenya. Unpublished M. Ed Thesis; Education in Curriculum Studies University of Nairobi, Kenya.

Owuor, N. (2012). Higher Education in Kenya: The Rising Tension between Quality and Quality in the PostMassification period. Higher Education Studies, 63-97.

Parker, T. (2011). Student Teacher Anxiety Related to the Teaching Practicum. EğitimAraştırmaları-Eurasian Journal of Educational Research, 42, 207-224.

Peter M. Gathara, (2011). Continuing Professional Development for Secondary School Teachers in Kenya; Policies, Trends and Practices: A Case of Kirinyaga District. Unpublished PhD Thesis; School Of Education, Kenyatta University.

Republic of Kenya. (2005). Kenya Education Sector Support Programme 2005-2010. Ministry of Education Science and Technology: Government Printers. 
Republic of Kenya. (2014). National Education Sector Plan, Ministry of Education Science and Technology. Volume One, pp 214 Basic Education Programme Rationales and Approach2013/2014-2017/2018: Government Printers.

Republic of Kenya (2005). Sessional Paper No 1 of 2005: A Policy Framework for Education, Training and Research. Nairobi: Government Printers.

Republic of Kenya (2012). Sessional Paper No 14 of 2012 on Reforming Education and Training Sectors in Kenya .Nairobi: Government Printers.

Sağ, R. (2014).The Course of Pre-Service Teachers' Expectations in School Practices and the Factors Affecting Their Expectations. Creative Education, 5, 353-371.

Tabot, B. A., \& Nyandusi M. C., (2012).Effect of Contextual Characteristics of Teaching Practice Schools on Student Teachers' Performance in Kenya. Journal of Emerging Trends in Educational Research and Policy Studies.Volume; 3, pp. 247-256.

Tabot, BenedictaAiyobei, (2015). Contextual Characteristics of Teaching Practice Schools and Supervision of Student Teachers in Kenya. Journal of Educational Policy and Entrepreneurial Research, Vol. 2, pp. 2408-770.

Wambugu, P., Barmao, A., \& Ng'eno, J., (2013). Student Teachers' Perceptions of Teaching Practice Assessment in Egerton University, Kenya. Education Journal. Vol. 2, No. 4, pp. 169-175.

Williams, T., \& Williams, K. (2010). Self-efficacy and performance in mathematics: Reciprocal determinism in 33 nations. Journal of Educational Psychology, 102 (2), 453-466.

Zeichner, K., (2010). Rethinking the Connections between Campus Curses and Field Experiences in College- and University-Based Teacher Education. The Journal of Teacher Education, 61, 89-99. 